large quantity of Romano-British pottery, but it was dug with metal implements, probably of iron.

There are two caves at Crayford within 3 feet 3 inches of each other; they are exposed in the side of a chalkpit connected with the brick-fields. One of them measured, from the surface to the chalk, about 18 feet ; thence to the floor, 17 feet 6 inches. 'The floor was of flints, about 6 inches thick, which had been taken up at one part and piled in a heap on the other side of the cave; about a quarter of the area, an irregular oval of 18 feet diameter, had been so treated. From this floor rose an obtuse cone of sandy clay 6 feet high, washed in very slowly and evenly by the rain. In the cone were found flint flakes, and one worked scraper with a rough core, from which flakes had been chipped, but no pottery. Above this, coarser soil and lumps of chalk, with several sorts of broken pottery, very coarse, black, spongy pot, scarcely baked, containing a large quantity of crushed shells not calcined, and a few pieces of pot made with coarsely-pounded chalk-all these either without ornament or only finger-nail marked; then finer pot of Roman moulds, and fine black ware, with a Samian plate. All were accompanied by large quantities of the bones of domestic and food animals for about a foot, then coarse earth and bones to the surface.

From about the period of the Roman deposit until now we know the value, and it would not be excessive to date the commencement of the deposit of mud and the abandonment of the cave perhaps at half that period earlier.

On the walls of this cave there are no marks of the implement by which it was excavated, and the conclusion is that the blocks were prised out.

The cave adjoining this fell in early and was soon obliterated.

Before knowing of these caves flint flakes and two "pot boilers" were found on the surface.

Clusters of these pits are either huddled into small areas sometimes or are spread out into lines, and they are frequent in spots which, from the supply of water, must have been thickly wooded, and so difficult of access, or from the bleakness of the situation unlikely to be noticed.

There is a cluster at Bexley of thirty-five in about three and a half acres, and another of forty-four.

Some pits which are-mostly filled up now, in the woods, are part of a system and are connected by banks and ditches, and the same banks with earthworks which are of a late stone age, and also with clusters of hut circles, and there is great probability that they served two usesretreat and storage, and as pitfalls, as to the last with an ingenious contrivance in one instance for driving animals down a deep covered way, either past a pit or, by an arrangement of a simple barrier, shunting them into it for the use of the camp.

F. C. SPURRELL

\section{PROF. GEIKIE ON THE GEOLOGY OF THE FAR WEST}

ON Monday the Ioth inst. Prof. Geikie reopened the class of geology in the University of Edinburgh by giving an account of his recent exploration of the western territories of North America. There was a large attendance of students and others.

The Professor, in the outset, reminded his students that last session he pointed out the remarkable lessons to be learned from the geology of the western regions of North America, more particularly in reference to the changes which had taken place on the surface of the earth from ordinary atmospheric causes. It was with special reference to those changes that he took a journey to the West. Had geology begun in those western territories, instead of among the old broken, gnarled, and contorted rocks of Europe and the east of America, its progress, at all events in some departments, would have been far more rapid than it had been. He had three objects in the expedition:-(I) To study the effects of atmospheric and river erosion upon the surface of the land; there being no region where these lessons could be learned with more wonderful impressiveness than in those great plateaux and table lands. (2) To mark the relation which the structure of the rocks underneath bore to the form of the surface. In this country and in Europe generally one was continually brought face to face with evidence of dislocations, protrusion of igneous rocks, contortions, and other complicated forms of geological structure which, save to experts in the subject, made it often difficult to realise how much of the present irregularity of the surface should be attributed to unequal waste by ordinary atmospheric causes, and how much to the direct effects of underground movements. The Western States and Territories of North America over which the strata, for thousands of. square miles, retained their original horizontality, presented remarkable facilities for the investigation of this subject, and had already, in the hands of King, Hayden, Powell, Dutton, and others, furnished ample materials for satisfactory discussion. (3) To watch with his own eyes some of the last phases of volcanic action. He had been familiar with the phenomena of active volcanic vents as displayed in Italy and the Lipari Isles; but he was anxious to see some of those marvellous evidences of the gradual decay of a vast volcanic area so well displayed in the famous region of the Yellowstone. The Professor went on to give a brief account of his journey. He stated that he was accompanied throughout by a former student of the class, Mr. Henry Drummond, F.G.S., whose constant hearty co-operation had been one main element in the success of the expedition. His route first lay westwards by railway into Colorado. In crossing the prairies towards the Rocky Mountains he noted, in the few sections that occurred, soft grey cretaceous or tertiary clays and marls. Getting down at some of the stations, and looking at the ant-hills and burrows of the prairie dog, he found that the surface of the prairies was veneered with a thin coating of a pinkish, finegrained sand, sometimes approaching to gravel, its colour being due to the presence of a great many small pieces of fresh felspar. It was clear that this mineral, as well as the quartz and occasional fragments of topaz, which he saw, did not belong to the strata on which they lay. In going west, the grains of sand, getting coarser, assumed the form of distinct pebbles, till, when he reached the mountains, they became huge blocks and boulders, evidently derived from the heights beyond. The cause of this wide diffusion of sand and gravel over the prairies was constantly present to his mind during the rest of the journey, and he took occasion on returning eastward to halt and make a more detailed examination of the subject.

The term "Rocky Mountains," he remarked, was a singularly unfortunate designation, under which had been included a great many independent and totally distinct mountain ranges. On most maps of North America a continuous line of lofty ridge was inserted down the axis of the continent and marked "Rocky Mountains." But no such ridge existed. The great plateau had been wrinkled by innumerable meridional folds which, dying out, were replaced by others. Some of these folds formed notable ranges of mountains with wide basins or plateaux between them. It was thus possible to cross the axis of the continent without traversing any mountains, rocky or otherwise. The line of the Union Pacific Railroad followed one of these natural routes. At its highest point (upwards of 8,000 feet), so little did the landscape suggest the altitude, that it had been found desirable to erect there a wooden placard with the title "Summit of the Rocky Mountains."

Crossing the Missouri River at Kansas City, and striking westwards to Denver, the Professor said he halted for 
a little while on the flanks of the great mountain range that formed the colossal bulwarks of the parks of Colorado. As seen from the prairies they rose in a picturesque line of peaks, visible in the clear atmosphere of these regions at an incredible distance, and looking at first like mere low islets, the greater part of their bulk being still hidden beneath the sea-like surface of the prairie. Composed of crystalline rocks these crests had been pushed as a great wedge through the cretaceous and tertiary rocks of the prairies, and had carried those rocks up with them in a grandly picturesque curve along their flanks. An excursion into some of the gorges or cañons by which the flanks of these mountains are trenched, brought to notice some interesting facts connected with the surface erosion of the district. He then found the source of the pink felspar sand of the prairie ; it had been borne down from this region, where great masses of pink granite, grey gneiss, and other crystalline rocks formed the core of the mountains, and were visibly crumbling into the same kind of pink sand and gravel. He found that the mountains had been covered with glaciers which had gone out into the plains and shed their huge horse-shoe shaped moraines where now everything was parched and barren.

Having crossed the watershed of the continent, he struck westward into the Uintah Mountains, one of the few ranges in that region that had an east and west direction. This range had been visited by Hayden, had been mapped by Clarence King and his associates, and its eastern enc had been carefully examined by Powell. It formed one of the most remarkable slevations in North America. Unlike the other mountainous high grounds it possessed no great central core of crystalline azoic rocks, but consisted of a vast flattened dome of red sandstones, dipping steeply down beneath mesozoic rocks on either flank. The precise geological age of these sandstones had been a matter of dispute. King had regarded them as carboniferous. In their lithological characters they much resemble some of the old red sandstone of Scotland, while some of the more compact portions, recalled the red Cambrian sandstones of Applecross and Assynt. One feature of surpassing interest in the Uintah Mountains was the evidence of enormous denudation, continued through a protracted cycle of geological time. The horizontality of the strata along the central parts of the range was such that terrace above terrace could be traced by the eye for miles around any commanding peak. The rocks there had escaped crumpling and fracture to a remarkable degree. It could therefore be seen that the deep gullies and clefts, the yawning precipices and cañons, the wide corries and vast amphitheatres by which the surface was so broken up had been produced not by underground disturbances but by erosion at the surface. Most of this tremendous denudation had doubtless been effected by ordinary atmospheric action. The speaker described the disintegrating effects of the remarkable daily vicissitudes of temperature in this region, the action of wind, as well as of melting snow, and occasional torrents of rain. But he showed that the mountains had also nourished large glaciers, and that these, filling up the main valleys had protruded into the plains beyond. They had left behind them numerous lake basins, some ground out of the horizontal sandstones, others dammed up by fallen moraine d'ebris.

Striking into one of the valleys, he found it crossed by beautiful horse-shoe moraines that had once formed a succession of lakes, of which the sites were now occupied by meadows. In these and other high grounds, however, it was the beaver, which, by its dams, converted even the small streams into a succession of shallow lakes. In most of these valleys there were hundreds of acres of bog land entirely due to the damming of the water by the beavers. The Uintah Mountains were flanked by ranges of low and sometimes fantastic hills, mesas or terraces, and isolated buttes or outliers, included under the general term "mauvaises terres" or "bad lands." This designation referred to the fact that the ground was everywhere crumbling down under the action of the weather, and nothing would grow upon it. The strata of these bad lands were flat or nearly so, and showed their lines of bedding with singular precision along the faces of the crumbling cliffs and slopes. They had an arid and almost ghastly aspect, grey, verdigris green and yellow, as they rose out of the sandy wastes at their base. It was from these strata that Prof. Marsh had obtained some of the marvellous reptilian and other forms which he had described from the eocene and cretaceous rocks of the West. Prof. Geikie narrated a ride through the forest lands of the mountains, and gave an account of how the party, benighted away from camp, had to pass the night without food on the bare ground, and how the forest around them caught fire.

The journey to the Yellowstone region was one of great tediousness and discomfort. Having letters from the Secretary of War and the Quartermaster-General of the United States, the party received every attention at Fort Ellis, where a pleasant day or two were spent, examining with the officers of the garrison the geology of the district. From this point the journey was performed on horseback and with a pack train of mules, the officer in command at Fort Ellis having furnished an outfit, scout and escort. The Professor gave a narrative of the traverse of the Yellowstone country, dwelling specially on the evidences of former successive periods of volcanic eruption, and on the proofs of intense glaciation to be observed in the ascent of the valley of the Yellowstone River. The tokens of a long period of volanic activity contemporaneous with the operations of the river, resembled those of Auvergne, but on a much larger scale. The mountains around consisted mainly of crystalline rocks such as gneiss, schist, and granite. The volcanic action appeared to have been chiefly confined to the valley. Sheet after sheet of lava had been poured out, and these, one after another, had been cut through by the river. The edges of some of the lava plateaux could now be seen crowning the summits of steep slopes or even cliffs far above the level of the stream below. So great had been the general erosion that no distinct craters remained now visible. But what appeared to be the stumps of some of these, filled up with a coarse volcanic agglomerate, were here and there observed. The lavas offered a vast and tempting field of investigation, presenting as they did a great number of petrographical varieties. Some of the obsidians were particularly interesting in their pumiceous and spherulitic characters. The Grand Cañon of the Yellowstone, cut out of these volcanic masses, was described as perhaps the most maryellous piece of mineral colour anywhere to be seen in the world. It had been cut out of tuffs and lavas, showing sulphur yellow, verdigris or emerald, green, vermilion, crimson, and orange tints, so marvellous that, if transferred to paper or canvas they would be pronounced incredible and impossible; the lecturer said he had spent a day in making a careful water colour study of this cañon, but he hardly expected to get any of his friends to believe in the truthfulness of his colouring.

During the ascent of the Yellowstone Valley the evidence of former extensive glaciation was abundant and conclusive. The party had hardly been in the valley a quarter of an hour when they descried, not far above the upper end of the first or lowest cañon, a large block among some mounds in the centre of the plain. This proved to be an erratic of coarse granitoid gneiss, lying among many others of smaller size. The mounds, manifestly moraines, curved in vast crescents across the broad plain of the Yellowstone. Further mounds and scattered blocks were noted in the ascent of this great expansion of the valley. On reaching the entrance of the second cañon, the Professor found it most exquisitely glaciated 
from bottom to top. It reminded him of the wonderful ice-polished precipice on the left bank of the Aar glacier, above the Grimsel. It was clear, therefore, that not only was this second cañon old; it was older than the glacial period; it had supplied a channel for the glacier that ground its way out from the mountains. Endeavouring to estimate the minimum thickness of the ice, he traced with the eye the glaciated surfaces up to the summit of the declivity - a height of at least 800 , perhaps 1,000 feet, - and they evidently went still higher. In going further up the valley, he found that the blocks of granite and gneiss, dropped by the glacier as it melted, went far above 1000 feet. He got them on the shoullers of one of the great hills overlooking the valley 1,600 or 1700 feet above the plain. The ice, therefore, must have been not less than $\mathrm{I}, 600$ or $\mathrm{r}, 700$ feet thick, and must have passed across intervening ridges into adjacent valleys. It thus appeared that not only did glaciers occupy the valleys of this region, but that some of them were of such thickness as to deserve the name of ice-sheets, covering the whole surrounding region.

Leaving the Yellowstone Valley, the party struck through the forest, and after a two days' ride reached the Upper Fire-Hole Basin of the now famous geyser region. Prof. Geikie gave a general sketch of the aspect of this district, and described the operations of one or two of the geysers which he witnessed. After the long ride through an arid region and dusty wastes, he tried hard here to get a pool to wash in, but could find nothing below $212^{\circ}$, and the only chance of getting a warm bath was to find some hole where the water had had time to cool after flowing out of the hot crater. The whole ground was honey-combed with holes, each filled with gurgling boiling water. One geyser, affectionately and gratefully known as "Old Faithful," went off with wonderful regularity every 63 minutes; the others were more capricious. The singular depositions round the orifices of eruption and round the margins of the pools on the cones were referred to, and among other interesting phenomena an account was given of the "Devil's Paint Pot," a mud geyser, throwing out white and brilliantly-coloured mud, boiling like a great vat of rather thick pasty porridge, and surrounded with small mud cones, each of which had formerly been a point of emission.

In quitting the Yellowstone region, it was impossible not to reflect with admiration upon the labours of the explorers who had first made known the wonders of this remote and inaccessible region. The Reports of Hayden and his associates were found to be most trustworthy and useful. Nor could one forget the sagacity with which Hayden proposed, and the enlightened liberality with which Congress enacted, that for all time the Yellowstone Region should be a tract set apart as a national park for the instruction and recreation of the people.

On the way out of the mountains by Henry's Lake and the head of the Snake River branch of the Columbia River, the travellers came upon a party of armed Indians, who explained that they were out of their reservation on their way to a council of Indians in Montana. As the great outbreak of the White River Utes, who killed Major Thornburgh and his men, took place only about ten days or so later, and as there was then some excitement among the tribes to the West, the geologists, though pleased at the time to have seen the noble red man in his war-paint among his native wilds, came to think that on the whole they might congratulate themselves on having seen no more of him. Only last year the Yellowstone country was dangerous from roving bands of Indians, several lives having becn lost in it. Leaving the Indians, who pursued their northward course in a bee-line, the travellers held westward along the edge of the vast basalt plateau of the Snake River-one of the most extensive lava fields in the world. A great plain, thousands of square miles in extent, had there been deluged with dark basalt. No cones or eminences appeared from which the lava migh have been poured. Perhaps the eruptions took place from open fissures. Here and there later cones had risen upon the plain, belonging, doubtless, to some of the later stages of the volcanic activity. Some of these cones still retained well-shaped craters.

Reaching eventually the basin of the Great Salt Lake, one of the first geological features that struck the travellers was the evidence of the former vast expansion of the Salt Lake. Lines of terrace ran as prominent features along the sides of the mountains, the highest of them standing at a height of nearly 1000 feet above the present level of the lake. Striking into some of the cañons descending from the Wahsatch Mountains into the Salt Lake Basin, Prof. Geikie found the rocks smoothed, polished, and striated by the glaciers that had come down from the heights and had brought with them great quantities of moraine matter. Mounds of rubbish blocked up the valleys here and there, and some of them he observed to descend to the level of the highest terrace. Hence when the Salt Lake extended far beyond its present area, and was about rooo feet deeper than now, the glaciers from the Wahsatch Mountains reached its edge and shed their bergs over its waters. Bones of the musk-ox had been found in one of the terraces, showing that an arctic fauna lived in this region during these cold ages.

On his return journey the Professor resumed the examination of the surface deposits of these prairies. Coming out of the Colorado Mountains, he noted, in connection with the gravel formerly observed, great quantities of a peculiar grey clay or loess inter-stratified with the gravel, and here and there containing a small terrestrial shell (Succinia vermeta). It was a freshwater deposit, one that had been swept by the waters coming down from the mountains over the prairie. It might be regarded as marking one of the phases in the period during which the gravel and sand were being thrown down. Tracing the gravel mounds over an extensive tract, he found that they had been deposited irregularly, as might have been the case from the action of water escaping tumultuously and interruptedly from the melting ends of the ice. The water currents would traverse the plain now in one direction, now in another. The whole prairie, for many leagues east from the mountains, must have been flooded with water derived from the melting ends of the great glaciers.

By these successive floods the gravel and sand were spread out irregularly over the plain, and during the same prolonged period of ablation of the ice there were here and there greater streams or periods of more muddy water, when the fine grey loess was diffused over the flats, as has taken place in the valleys of the Danube and Rhine. No doubt some of the fine detritus may be travelling eastward still, for though the rainfall over much of the prairie country is exceedingly slight, it may suffice to give the fine particles of sand and gravel an intermittent movement to lower levels.

\section{NOTES}

WE take the following from the Times:-The medals awarded and recommended by the Council of the Royal Society for the present year are: The Copley medal to Prof. Rudolph J. E. Clausius, of Bonn, for his well-known researches upon heat; the Davy medal to Mr. P. E. Lecoq de Boisbaudran for his discovery of gallium; a Royal medal to Mr. William Henry Perkin, F.R.S., for his synthetical and other researches in organic chemistry; and a Royal medal to Prof. Andrew Crombie Ramsay, F.R.S., for his long-continued and successful labours in geology and physical geograplny. These medals will be presented at the anniversary meeting of the Society, on December I, when Mr. W. Spottiswoode will deliver his first annual address as president. 